\title{
Impact of FDI on the Development of an Economy and the Growth in the Value of Exports of a Country
}

\author{
S. Sridevi, S. Chandramohan
}

\begin{abstract}
The flow of FDI into the country is anticipated to be in a position to expand productivity which will ultimately have an influence on the growth in national income in the form of the Gross Domestic Product (GDP) as well as in the form of increased exports. In other words, in order to enhance the country's overall performance in international trade, investment is genuinely necessary. There is a one-way relationship between FDI and export in which the value changes in FDl have an effect on changes in the value of exports. In the short term, the extend in the expense of FDl reasons a decline in the value of exports. While in the long term, the extend in the expense of FDl will reason an upward jab in the value of exports the increase in price will cause a upward jab in the fee of exports. . It is activated by the idea of FDI is a subsidizing in long term oriented so that the advantages to the economy, which incorporate export in general execution can be obtained in the long term. Hence, foreign countries can be instrumental in advancing exports from the host nations. As an ever increasing number of exports help lead a nation to expand its foreign exchange reserves and fabricate a strong financial position, in this manner, it tends to be appropriately said that FDI can not just build the export base of the domestic country but additionally adds to the overall growth of the host country.
\end{abstract}

Keywords : Export; Import; Economy; Investment; Trade.

\section{INTRODUCTION}

The International money related situation has been showing a period of change since the most recent two decades, where capital streams as outside guide have evaporated, and monetary organizations like World Bank and IMF alone have not had the option to get together the necessities of the creating nations. Thus, financial policymakers of creating economies go far in drawing in capital streams as Foreign Direct Investment (FDI) as an abnormal state of FDI is seen as an insistence of things to come monetary wellbeing of that nation. As a rule, FDI alludes to the capital inflows from outside nation that puts resources into the gainful limit of the host nation. FDI has accordingly turned into an indispensable part of the formative procedures received by practically all countries over the globe. Actually, FDI gives a success win circumstance to both the 'contributing nation' just as to the 'have nation'. The contributing nation can exploit the free advertise openness that it gets in the host nation. The host nation then again can build its budgetary assets for advancement, support send out aggressiveness, and increment its work profitability by

Revised Manuscript Received on September 25, 2019

S.Sridevi, Ph D Scholar, Alagappa Institute of Management, Alagappa University, Karaikudi

Dr.S.Chandramohan, Professor, Alagappa Institute of Management, Alagappa University, Karaikudi fortifying its aptitude base and improving innovative capacities. The job of FDI in the development procedure of the host nation has for quite some time been a point of discourse. A few of the discourses and studies uncover that there is a solid and positive connection among FDI and development. Aside from going about as a motor for innovation move (or dispersion), FDI likewise animates household venture, global exchange, extend local investment funds, increment its remote trade holds in this manner redressing its Balance of Payments position. Every one of these variables together contribute towards the development of a country. Fares, then again, is additionally considered as an instrument of monetary development and encourages effective generation of products and enterprises by increasing relative bit of leeway over different nations. The examples of overcoming adversity of East and South-East Asian nations recommend that FDI is viewed as a useful asset of fare advancement for the residential nation. A few examinations have likewise affirmed that FDI through global partnerships (MNCs) have more noteworthy favorable circumstances over residential firms in regard of fare execution. Outside firms carry with them numerous immaterial resources as innovation, abilities, brand names, promoting techniques, all inclusive set up advertising channels and experience of working in worldwide markets. In this manner, outside nations can be instrumental in advancing fares from the host nations. As an ever increasing number of fares help lead a nation to expand its outside trade saves and fabricate a solid monetary position, in this manner, it very well may be appropriately said that FDI can not just build the fare base of the residential nation yet additionally adds to the general development of the host nation. In this manner, the paper attempts to demonstrate a between connection between FDI, fares and development, and the example proof is gotten from the important information of Indian Economy. Subsequently, the primary segment of the paper manages the information utilized and the strategy embraced for the examination. The last period of the paper manages the definition of theories and concentrates the connection between the three factors by receiving basic and different relapse strategies. It needs little accentuation that a country's global intensity today essentially relies on the development and innovative dynamism that it receives. Financial policymakers, along these lines, go out their approach to draw in Foreign Direct Investments (FDI), as an abnormal state of FDI is seen as an impetus of monetary development for the host nation. 


\section{LITERATURE REVIEW}

Various econometric investigations have been done in the ongoing past to demonstrate the legitimacy of the connection between FDI mixture in an economy and monetary development. A board information investigation was done to look at the connection between Foreign Direct Investment (FDI), monetary advancement and financial development utilizing Generalized Method of Moments in a gathering of 70 created and creating nations from 1988 to 2002 (Choong and Lam, 2011). It was discovered that FDI has a negative and huge effect on financial development in creating nations. The elucidation for the negative indication of FDI is that the powerless guidelines and the low level of the budgetary part improvement in creating nations lead to misallocation of this private capital stream, which diminishes and even turns around its effect on financial execution. The discovering bolsters the idea that a specific degree of money related division advancement is a noteworthy and essential for FDI to positively affect monetary development. The significant discoveries of the investigation are that FDI by and large positively affects the financial development pace of nations. To have nation, FDI offers significantly more than should be expected speculation as it raises the factor profitability just as upgrades the capacity to all the more likely coordinate the local businesses with worldwide markets. A period arrangement examination was likewise utilized to demonstrate the causal connection among FDI and monetary development of Bangladesh utilizing yearly information from 1975 to 2005 (Md. Gazi Salah Uddin and Md. Wahidul Habib, 2008). The Granger Causality test and Error Correction Models were utilized dealing with stochastic properties of the factors. The outcomes showed that FDI and fares are co-incorporated and recommend a single direction causation from FDI to send out development. This suggests FDI causes send out development over the long haul however does not impact in the short-run. Over the most recent three decades, FDI streams have become quickly everywhere throughout the world. This is on the grounds that many creating nations see FDI as a significant component in their procedure for monetary advancement. The FDI has the two advantages and expenses and its effect is dictated by the nation's particular condition when all is said in done and the arrangement condition specifically. The connection among FDI and monetary development is extremely questionable as it shifts from nation to nationNotwithstanding the examinations made which managed surveying the general effect of FDI on development, an investigation made by Singh (2011) concentrated on the effect of outside speculation on host nation mechanical structure with uncommon reference to India's assembling area during post change period. In addition, the center variable of the investigation to be specific remote nearness shown positive and huge relationship with modern market focuses. Roy and Mandal (2009), analyzed the elements between financial development and FDI for a chose gathering of Asian economies in particular India, China, Hong Kong, Malaysia and Philippines. This paper analyzed the issue of swarming in or out impact among remote and household Investment over the long haul. In spite of the fact that it might be seen normal to contend that FDI can pass on extraordinary points of interest to have nations. Laura (2003) demonstrated that the advantages of FDI fluctuate incredibly crosswise over divisions by looking at the impact of FDI on development in the essential, assembling and administrations area. An exact investigation utilizing cross country information recommended that complete FDI applies a questionable impact on development. Another paper (Ilan, 2007) explores the effect of remote direct speculation (FDI) on monetary development utilizing nitty gritty sectoral information for FDI inflows to Indonesia over the period 1997-2006. In the total level, FDI is seen to positively affect monetary development. Notwithstanding, when representing the diverse normal development execution crosswise over segments, the advantageous effect of FDI is never again obvious. When inspecting various effects crosswise over parts, estimation results demonstrate that the piece of FDI matters, for its impact on financial development with not many divisions indicating positive effect of FDI and one segment even is demonstrating a strong negative effect of FDI inflows. An examination made by Balamurali (2004) looks at the connection between outside direct venture and monetary development of Sri Lanka for the period 1977-2003 utilizing Johansen's full data most extreme probability strategy by thinking about connection between genuine total national output, remote direct speculation, household speculation and receptiveness of the exchange arrangement system. The outcomes demonstrate that remote direct ventures apply an autonomous effect on financial development and there is bidirectional causality between outside direct speculation and monetary development.

\section{Objectives of the study}

- To study the impact of FDI on the development of an economy.

- To study the relationship between FDI and exports.

\section{DETERMINANTS OF EXPORT}

Fare advancement techniques addition included significance in exchange progression system. On one hand creating nations are confronting twin shortages, in particular, financial deficiency and exchange shortfall. Then again, outer obligation emergencies make further money related issues. In such sorry condition of money related position, the sole inflow of FDI isn't adequate and the development of fare division for the improvement of budgetary unsettling influence likewise should be tended to. In this regard, we distinguish different determinants of fares. Fare development is fundamentally controlled by outside components, for this we utilize two factors FDI and genuine conversion scale. In any case, sends out are additionally influenced by residential elements. In this regard we fuse GDP, GDP development rate, roundabout charges, correspondence offices, investment funds, industrialisation, work power and authority advancement help.

\section{Production Level}

It is the supply side determinant of fares [see Bertil (1968)]. A more elevated amount of generation is the fundamental driver of fare development, since overflow of yield can be depleted in universal markets. In a nearby

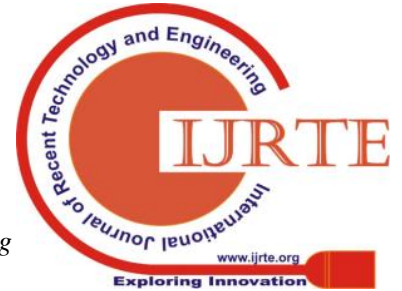


economy excess of generation prompts fall in costs, which, thus, makes cynicism among makers. In an open economy such surpluses make remote saves by sending out generation. So we anticipate the positive effect of GDP on fares development. In exact writing Kumar (1998) affirms the positive effect of GDP on fares.

\section{Real Exchange Rate}

A fall in the relative local costs because of conversion scale deterioration, which makes sends out less expensive in global markets and, consequently bring about expanded interest for fares. Accordingly we expect positive effect of genuine swapping scale on fare development.

\section{Communication Facilities}

In this time, when time is contracting, the significance of correspondence offices has turned out to be progressively significant. For the estimation of correspondence offices we utilize two factors, in particular, the quantity of TVs and the quantity of phone sets being used. These two factors have additionally been advocated in experimental writing [Kumar (1998)]. This substance downloaded from 14.139.181.195 on Thu, 22 Aug 2019 10:08:16 UTC All utilization subject to https://about.jstor.org/terms FDI and Exports in Developing Countries 743 Expansion of such offices has good impact for investigation and abundance to the world markets. Consequently, we expect that the arrangement of such offices will positively influence sends out.

\section{Indirect Taxes}

The impact of this variable is relied upon to be unfriendly on generation choices. Be that as it may, we can't preclude the likelihood of constructive outcome on fares because of financial motivating forces by government. In particular, if government gives charge exclusions to the fares division, higher paces of backhanded duties can have the negative impact on residential interest bringing about exportable excess.

\section{Savings}

For the most part, in creating nations the extent of reserve funds utilized for non-beneficial elements, for instance obtaining of gems, property, and so forth., is bigger. In this way higher investment funds result is huge volume of merchandise made accessible for fares. So we anticipate positive effect of this variable on fares.

\section{Industrialisation}

The horticultural yield is exposed to vulnerability, especially in light of activity of nature's caprices. In like manner, presently multi day, just based on horticultural yield no nation has more prominent wages and yields. Then again, the industrialisation brings about greatest usage of normal and HR of the nation and mechanical yield is pretty much steady. In this way industrialisation will give more noteworthy boost to yield and national pay of the nation. Industrialisation additionally advances farming division and horticulture inspires the modern segment. The modern improvement will have the impact of building up the unified and related parts. The circumstance of determined shortfall in equalization of installments is ascribed to focus in farming fares, falling costs of fares, the imports limitations by rich nations and the expanding import bill because of expanded interest for oil and made items, and so on. Through industrialisation a nation can improve mechanical creation; supplant the horticulture sends out by the modern fares, which order sensible and stable costs on the planet markets. Besides, industrialisation diminishes reliance on imports by starting the procedure of import substitution. Keeping in view every such contention, we expect that industrialisation will have great impact on fares.

\section{Foreign Direct Investment}

In experimental writing the job of FDI in fares advancement is dubious. Numerous investigations discover constructive outcome of FDI on fares. The primary reason basic is the fare direction of MNCs. Moreover so as to advance fares government can embrace FDI-drove send out development systems with twin goals of catching the advantages of both FDI inflow and fares development. Then again, numerous examinations discover immaterial or powerless effect of FDI on fares. Such examinations call attention to that the job of FDI in fare. In the event that the thought process behind FDI is to catch local market (levy bouncing sort venture), it may not add to trade development. Then again, if the thought process is tap fares showcases by exploiting the nation's similar bit of leeway, at that point FDI may add to send out development.

\section{CONCLUSION}

FDI can supplement neighborhood formative endeavors by boosting trade intensity, producing business and reinforcing the aptitude base, improving innovative capacities (move, dissemination and age of innovation), and expanding budgetary assets for advancement. It can likewise help plug a nation in the universal exchanging framework, just as advance a progressively focused business condition. In perspective on this, India should keep on finding a way to guarantee an empowering business condition to improve India's engaging quality as a speculation goal. But there have been a couple of components of worry for India. As per the most recent reports distributed by Economist Intelligence Unit, FDI inflows in India are set to increment significantly yet would stay well underneath potential. The report says that 'India's capability to pull in expanded FDI inflows is huge, albeit poor framework, over the top organization, work showcase wasteful aspects, and interdepartmental wrangling will slow the pace of opening in numerous parts'. Subsequently, it is profoundly prescribed to the arrangement producers of India that intense advances must be taken to improve infrastructural offices and increment work efficiencies which can be viewed as a rebuilding device to build FDI inflows in India. There is not really any Greenfield Investments being occurred up until now. At long last, India ought to deliberately progress in the direction of drawing in more noteworthy FDI into R\&D as a methods for reinforcing the nation's innovative limits. In spite of the fact that approach producers are taking a gander at FDI as the essential wellspring of assets, yet it must be mulled over that FDI isn't the main arrangement of fast development and improvement. India needs to set up a far reaching formative methodology which incorporates being available to exchange and FDI. 


\section{REFERENCES}

1. Ayanwale, A. B. (2007). "FDI and Economic Growth: Evidence from Nigeria". African Economic Research Consortium.

2. Fortanier, F. (August 2007). "Foreign Direct Investment and Host Country Economic Growth: Does the investor's country of origin play a role?". Transnational Corporation.

3. Habib, M. G. (2009). "Causal Relationship between FDI and export for Bangladesh: A Time-Series analysis". Asian Economic Review.

4. Kumar, G. (2011). "Causality between FDI and economic growth: A comparative study of India and China". Man and Development.

5. Lam, C. K.-Y. (2011). "Foreign Direct Investment, Financial Development and Economic Growth: Panel data Analysis". The IUP Journal of Applied Economics.

6. Ljungwall, C. (2007). "Financial Sector Development, FDI and Economic Growth in China". China Center for Economic Research.

7. Ministry of Commerce \& Industry, Govt. Of India. (2012, January). Department of Industrial Policy and Promotion. Retrieved from FDI Statistics: http://www.dipp.nic.in/

8. Mousumi Bhattacharya, S. N. (2011). "The Interrelationship between Merchandize Trade, Economic Growth and FDI Inflows in India". South-Eastern Europe Journal of Economics.

9. Ramkishen S. Rajen, S. M. (2009). 'How can India Increase its Attractiveness as a Destination for FDI?' In R. S. Rajen Monetary Investment and Trade Issues in India (pp. 127-151). New-Delhi: Oxford.

10. Samrat Roy, K. M. (2009). "Empirical Evidence on the Relationship between Foreign Direct Investment and Economic Growth: A Cross-Country Exploration in Asia".

11. Singh, J. (2011). "Concentration in India's Manufacturing Industry: Impact of Investment Liberalization”. Man and Development. 